\title{
Korzyści i zagrożenia zdalnego nauczania z perspektywy studentów oraz nauczycieli akademickich wybranych krakowskich uczelni
}

\author{
Benefits and risks of remote teaching from a students' and \\ academic teachers' prespective of selected Cracow universities
}

\begin{abstract}
Streszczenie
Sytuacja epidemiczna w Polsce i na świecie stanowiła swoisty impuls do zmiany edukacji z trybu stacjonarnego na zdalny, do którego konieczne było korzystanie z odpowiednich do tego celu metod i narzędzi. Okoliczności te stały się wyzwaniem nie tylko dla studentów, ale również dla nauczycieli akademickich, którzy w jak najlepszy sposób próbują przekazać przyszłym absolwentom wiedzę, kompetencje i umiejętności potrzebne młodym ludziom do pracy w zawodzie.

W niniejszej publikacji podjęto próbę omówienia teoretycznych aspektów edukacji zdalnej w oparciu o dostępną literaturę. Opisano przeprowadzone badania oraz wyniki, jakie uzyskano na podstawie odpowiedzi respondentów na autorski kwestionariusz ankiety, który został przeprowadzony za pomocą Google Forms w dniach od 10 marca do 13 kwietnia 2021 roku. W badaniu wzięło udział 115 nauczycieli akademickich oraz 229 studentów. Sondaż diagnostyczny stanowił anonimową formę uzyskiwania odpowiedzi na 12 pytań. W kwestionariuszu ankiety zapytano m.in. o narzędzia wykorzystywane do zajęć online oraz stosowane w celu
\end{abstract}

1 Agnieszka Potera, Polska, e-mail: agapot@op.pl, ORCID ID: https://orcid.org/0000-00024458-9609. 
skontaktowania się w relacji nauczyciel akademicki-student, student-student. Badano również zagadnienie koncentracji na zajęciach oraz problemy z komunikacją. W artykule rozważano też korzyści i zagrożenia związane z nauką na odległość na wybranych krakowskich uczelniach wyższych z perspektywy nauczycieli akademickich oraz studentów. Stwierdzono, że najbardziej efektywne zdobywanie wiedzy następuje poprzez połączenie nauczania w formie zdalnej oraz stacjonarnej. Tryb hybrydowy obniża poziom zagrożeń związanych z e-learningiem oraz sumuje korzyści wynikające z nauczania tradycyjnego oraz na odległość.

\title{
Słowa kluczowe:
}

zdalne nauczanie, technologie informatyczno-komunikacyjne, uczelnie wyższe, COVID-19, zagrożenia, korzyści

\begin{abstract}
The epidemiological situation in Poland and in the world was a specific impulse to change education from stationary to remote education, for which it was necessary to use appropriate methods and tools. These circumstances have become a challenge not only for students, but also for academic teachers who try to provide future graduates with the knowledge, competences and skills needed by young people to work in the profession.

This publication attempts to discuss the theoretical aspects of remote education based on the available literature. The research conducted and the results obtained on the basis of the respondents' responses to the proprietary questionnaire, which was carried out using Google Forms from March 10 to April 13, 2021, are described. 115 academic teachers and 229 students participated in the study. The diagnostic survey was an anonymous form of obtaining answers to 12 questions. In the questionnaire, the questionnaire was asked about the tools used for online classes and used to contact the academic teacher - student, student - student relationship. Concentration in classes and communication problems were also investigated. The article also considers the benefits and risks of distance learning at selected Krakow universities from the perspective of academic teachers and students. It was found that the most effective acquisition of knowledge occurs through a combination of distance and stationary teaching. The hybrid mode reduces the level of threats related to e-learning and sums up the benefits of traditional and distance learning.
\end{abstract}

\section{Keywords:}

distance learning, information and communication technologies, Universities, COVID-19, threats, benefits 


\section{WPROWADZENIE}

W związku z zagrożeniem epidemicznym dnia 11 marca 2020 roku zamknięto wszystkie szkoły i uczelnie wyższe w Polsce. Okoliczności te były przełomowe dla zmian metod i narzędzi stosowanych w szkolnictwie. Trudna rzeczywistość wymusiła na wszystkich dostosowanie się do obostrzeń wdrażanych w Polsce. Mimo wieloletniego użytkowania nowoczesnych narzędzi informatycznych, które zmodyfikowały sposób pracy, nauki oraz standard życia, nigdy wcześniej nie wprowadzono edukacji zdalnej na taką dużą skalę. Znaleźliśmy się w nowej rzeczywistości, w której rozpoczęła się era nowoczesnych technologii informatycznych i telekomunikacyjnych w kształceniu. Wielu naukowców oraz dydaktyków przed pandemią COVID-19 wskazywało na możliwości urządzeń mobilnych wykorzystywanych w nauczaniu oraz uczeniu się, w celu doskonalenia edukacji (Hojnacki, Kowalczuk, Kudlek, Polak i Szlagor, 2011). A. Syguła dostrzegał ogromny potencjał nowoczesnych technologii, za których pośrednictwem ułatwione zostanie przystosowywanie do dynamicznie zmieniającego się świata. Czy nowe technologie wprowadzone w nauczaniu stały się sprzymierzeńcem studentów oraz nauczycieli akademickich, czy też ich wrogiem? Artykuł pozwoli przybliżyć to zagadnienie, zwracając uwagę na aspekty przemawiające za i przeciw nauczaniu na odległość z dwóch różnych punktów widzenia.

Celem tej pracy jest rozważenie korzyści i zagrożeń związanych z edukacją zdalną na wybranych krakowskich uczelniach wyższych z perspektywy nauczycieli akademickich oraz studentów. Motywacją do podjęcia badań w tym kierunku była sytuacja epidemiczna w Polsce oraz związane z tym przejście na całkowitą edukację $\mathrm{w}$ formie zdalnej.

W pierwszej części pracy zostały omówione teoretyczne aspekty przedmiotu pracy w oparciu o dostępną literaturę, w celu wprowadzenia w tematykę oraz możliwość refleksji. Rozważano również plusy i minusy edukacji zdalnej. Kolejno analizowano wyniki badań, pozwalając wysnuć pewne wnioski oraz sugestie, które umożliwią podjęcie właściwych decyzji usprawniających funkcjonowanie uczelni w przyszłości.

\section{TECHNOLOGIE INFORMATYCZNE I TELEKOMUNIKACYJNE WYKORZYSTYWANE W NAUCZANIU NA UCZELNIACH WYŻSZYCH}

Edukacja na odległość, inaczej nazywana zdalnym nauczaniem (D-learning z języka angielskiego distance learning) - jest metodą uczenia, która polega na od- 
izolowaniu nauczyciela od ucznia i grupy innych osób, które chcą posiąść wiedzę w celu zastąpienia konwencjonalnej nauki odbywającej się w trybie stacjonarnym pośrednimi metodami m.in. za pomocą tradycyjnej poczty oraz technologii komunikacyjnej (Kaplan, 2017). Zdalna edukacja opiera się na najnowszych trendach związanych z mobile learningiem, wirtualnymi uczelniami, e-książkami, systemami ułatwiającymi wytwarzanie, przechowywanie oraz wyszukiwanie informacji (Diarra i Kaczmarek, 2003). Istnieje wiele różnych narzędzi, które pozwalają na nawiązanie kontaktu, przekazywanie wiedzy, podnoszenie kompetencji oraz umiejętności na odległość. Wiąże się z tym dostosowanie pewnych działań edukatorów, które umożliwią zdobywanie, utrwalanie oraz praktykowanie wiedzy w przystępny dla studenta sposób.

Nauczyciele akademiccy wykorzystują technologie informacyjno-komunikacyjne w działalności dydaktycznej, badawczej oraz do innych celów związanych z aktywnością zawodową. Przykładem zastosowań programów w obszarze edukacji są wybrane części aplikacji z oprogramowaniem: do obsługi toku studiów, wspierającym proces dydaktyczny, specjalistycznym z danej dziedziny nauki, antyplagiatowym, użytkowym (edytor tekstów, arkusz kalkulacyjny, program do tworzenia prezentacji, program pocztowy z terminarzem), biblioteki cyfrowe, pakiety statystyczne, elektroniczna legitymacja, Web 2.0. (Stachowiak, 2012).

\section{KORZYŚCI I ZAGROŻENIA ZDALNEGO NAUCZANIA W LITERATURZE}

Nowe technologie dają większe możliwości nie tylko poprzez łamanie barier geograficznych, ale stając się bardziej interaktywne, ułatwiają komunikację. Sympatycy nauczania zdalnego dostrzegają korzyści płynące z opracowanych wcześniej e-learningu oraz przystosowanych do tego celu narzędzi. Z kolei osoby z krytycznym spojrzeniem na edukację odbywającą się na odległość zwracają uwagę na zagrożenia, jakie mogą się za nią kryć. Wielu autorów podkreśla możliwości zdalnej edukacji związane z udostępnianiem materiałów edukacyjnych w łatwy i szybki sposób, oszczędzając czas oraz ograniczając koszty. Według T. Białobłockiego oraz J. Moroza naukowcy nowego systemu nauczania skłonni są do łączenia starych i nowych metod kształcenia, tłumacząc to lepszym przyswajaniem wiedzy. Twierdzą oni również, że ludzie „bardzo dużą wagę przywiązują do bezpośrednich kontaktów międzyludzkich i nawiązania spontanicznej interakcji” (Białobłocki i Moroz, 2006, s. 158). E. Szkurłat wyróżnia w swojej pracy trzy grupy zagrożeń związanych z e-learningiem w kształceniu akademickim. Należą do nich zagrożenia edukacyjne, organizacyjne oraz ekonomiczne (Szkarłat, 2015, s. 67-68). J. Mi- 
schke stwierdził, że „nauczanie tradycyjne i e-edukacja są z sobą nierozerwalnie związane i sztuczne ich dzielenie do niczego dobrego nie prowadzi” (Mischke, 2004, s. 53). Dostrzegano korzyści płynące z łączenia edukacji stacjonarnej oraz możliwości nauki w trybie zdalnym. Wskazywano również na takie wartości e-learningu jak: zwiększenie elastyczności, efektywności edukacji oraz różnorodność środków i metod stanowiących odpowiednie uzupełnienie kształcenia (Bednarek, Lubina, 2008, s. 102; Tanaś, 2004, s. 36).

Tabela 1. Zalety i wady nauczania zdalnego

\begin{tabular}{|c|c|}
\hline Zalety zdalnego nauczania & Wady zdalnego nauczania \\
\hline $\begin{array}{l}\text { - czas oraz tempo nauczania dostosowane do } \\
\text { dyspozycyjności uczących się } \\
\text { - nieograniczony terytorialnie i czasowo } \\
\text { dostęp do wiedzy } \\
\text { - dowolna liczebność uczestników } \\
\text { - rozwijanie umiejętności analizowania poda- } \\
\text { nych informacji } \\
\text { - podnoszenie kompetencji organizacyjnych } \\
\text { - indywidualizacja metod i narzędzi kształce- } \\
\text { nia do odbiorcy } \\
\text { - oszczędności związane z kosztami podróży, } \\
\text { pobytu, zakwaterowania }\end{array}$ & $\begin{array}{l}\text { - brak dostępu do narzędzi, takich jak: kom- } \\
\text { putery, laptopy, oprogramowanie oraz Internet } \\
\text { - pozbawienie bezpośredniego kontaktu } \\
\text { z nauczycielem } \\
\text { - izolacja od innych uczących się } \\
\text { - konieczność automotywacji } \\
\text { - brak grup wsparcia } \\
\text { - problemy techniczne } \\
\text { - trudności związane z nauczaniem (brak } \\
\text { umiejętności poruszania po Internecie) } \\
\text { - niepewność, czy poprawnie wykonano } \\
\text { zadanie }\end{array}$ \\
\hline
\end{tabular}

Źródło: Opracowana na podstawie (Barczak, Florek, Jakubowski, Sydoruk 2006, s. 32, 47), (Rutkowska, 2002, s. 61,62), (Galwas, 2002, s. 170), (Barczak, Florek, Jakubowski, Sydoruk, 2006, s. 32).

\section{CHARAKTERYSTYKA PRÓBY BADAWCZEJ}

Badania ankietowe przeprowadzono za pomocą Google Forms w dniach od 10 marca do 13 kwietnia 2021 roku, w których łącznie wzięło udział 115 nauczycieli akademickich oraz 229 studentów uczelni znajdujących się na terenie miasta Krakowa. Najwięcej odpowiedzi uzyskano od respondentów prowadzących zajęcia oraz uczących się w Akademii Górniczo-Hutniczej oraz Akademii Wychowania Fizycznego. Stosunkowo mniej wyników otrzymano od nauczycieli akademickich oraz studentów z Uniwersytetu Jagiellońskiego, Politechniki Krakowskiej, Uniwersytetu Ekonomicznego, Uniwersytetu Pedagogicznego.

Spośród ankietowanych nauczycieli akademickich 36,5\% stanowiły kobiety, a mężczyźni 63,5\%. Z kolei w grupie studentów 62,9\% odpowiadających to panie, a $37,1 \%$ panowie. 


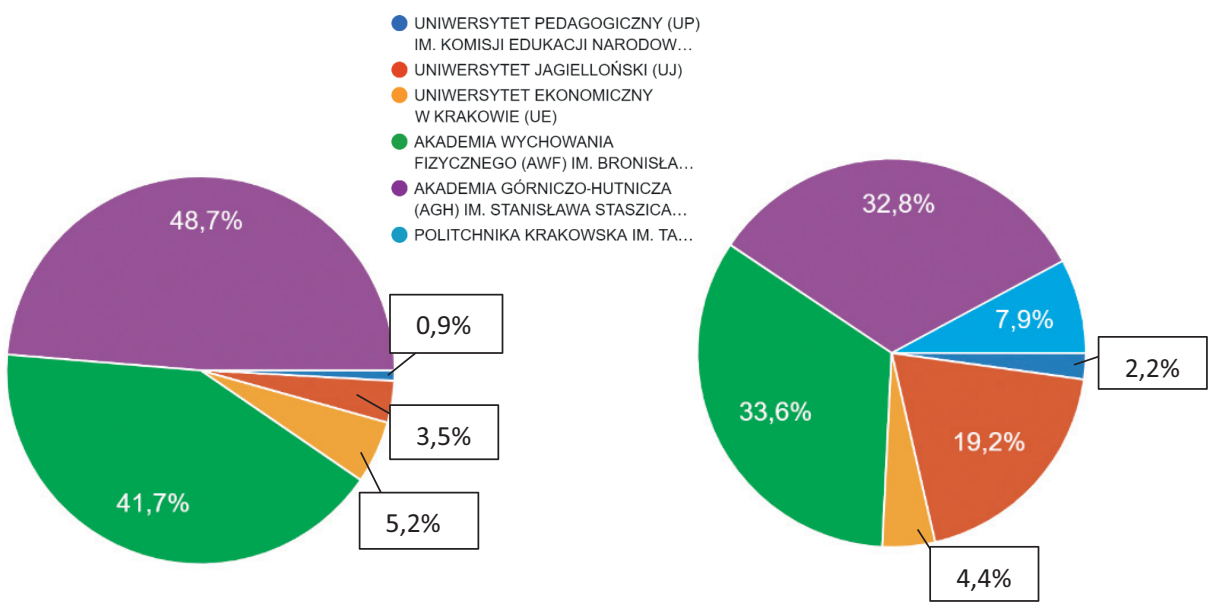

Ryc. 1. Procentowy udział ankietowanych

Ryc. 2. Procentowy udział ankietowanych nauczycieli akademickich z danej krakowskiej studentów z danej krakowskiej uczelni uczelni

Źródło: opracowanie własne.

\section{METODY BADAŃ}

Metodą wykorzystywaną w przeprowadzonych badaniach był sondaż diagnostyczny, do którego wykorzystano dwa odmienne autorskie kwestionariusze ankiety (jeden skierowany do grupy nauczycieli akademickich, drugi do studentów). Narzędzie badawcze stanowiło anonimową formę uzyskiwania odpowiedzi na 12 pytań, w tym 3 pytania otwarte, 2 pytania półotwarte, 7 pytań zamkniętych, z czego w 5 uwzględniono pięciostopniową skalę Likerta. Kwestionariusze ankiety zawierały informacje dotyczące m.in. płci, uczelni, do której respondent przynależy. Zapytano również o narzędzia wykorzystywane do zajęć online oraz stosowane w celu skontaktowania się w relacji (student-student, nauczyciel akademicki-student). W badaniu brano pod uwagę zagadnienie koncentracji na zajęciach oraz problemy z komunikacją. Poproszono o wypisanie korzyści, zagrożeń oraz własnych przemyśleń związanych z edukacją zdalną. 


\section{WYNIKI BADAŃ}

Najczęściej wskazywane przez nauczycieli akademickich oraz studentów narzędzia, które są wykorzystywane podczas zajęć online, to: Microsoft Teams, Uczelniane platformy e-learningowe, Zoom, ClickMeeting, poczta elektroniczna, Skype, Cisco Webex Meetings, Google Hangouts Meet, Discord, Google Docs.

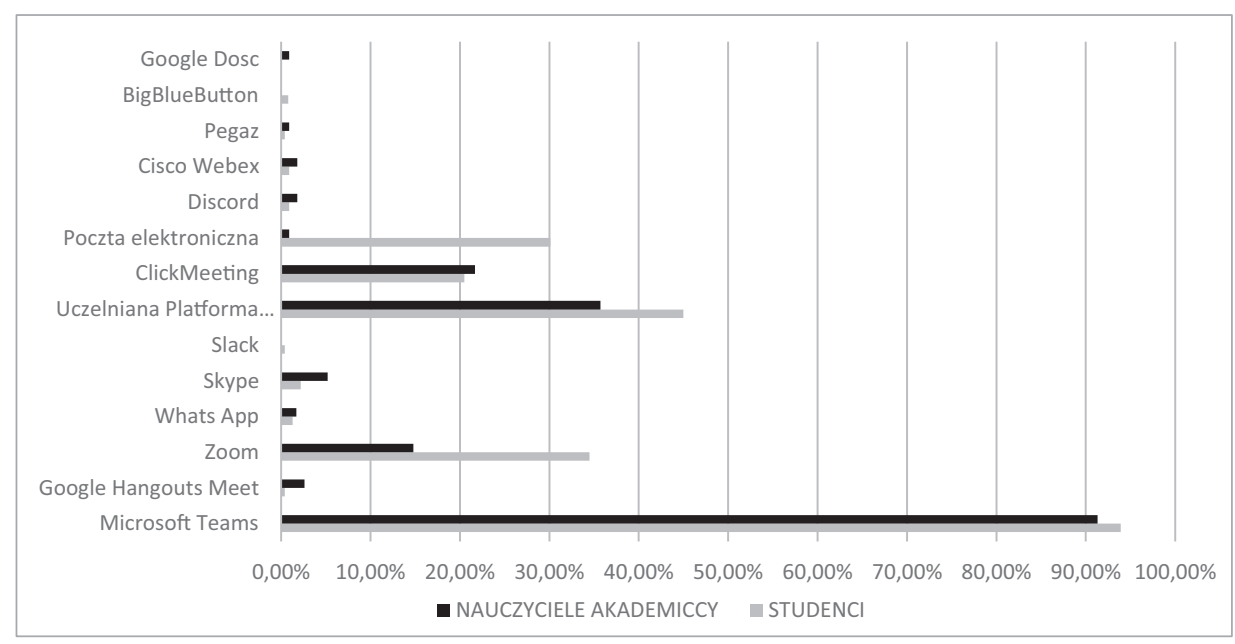

Ryc. 3. Narzędzia cyfrowe wykorzystywane w trakcie zajęć na wybranych krakowskich uczelniach Źródło: opracowanie własne.

Nauczyciele akademiccy w celu skontaktowania się ze studentami wybierają w przeważającej mierze takie narzędzia jak: poczta elektroniczna (85,2\%), Microsoft Teams (84,3\%), ClickMeeting (11,3\%), Zoom (8,7\%), Skype (5,2\%), WhatsApp (3,5\%). Z kolei studenci w trakcie prac grupowych wykorzystują głównie: Messenger (92,6\%), Microsoft Teams (59,45\%), Discord (13,7\%), Zoom (8,7\%), WhatsApp (5,4\%).

W kolejnym pytaniu nauczyciele zostali poproszeni o ocenę możliwości realizacji założonych celów edukacyjnych w nauczaniu zdalnym, które zostały przedstawione na wykresie 4.

W dalszej kolejności poproszono nauczycieli akademickich o zaznaczenie, czy odczuwają problemy z komunikacją ze studentami. Z kolei studentów o trudnościach w porozumiewaniu z nauczycielami akademickimi. Wyniki zostały zamieszczone na wykresie 5 . 
Czy uważa Pani/Pan, że jest w stanie zrealizować założone cele edukacyjne w takim samym stopniu w nauczaniu zdalnym, jak i stacjonarnie?

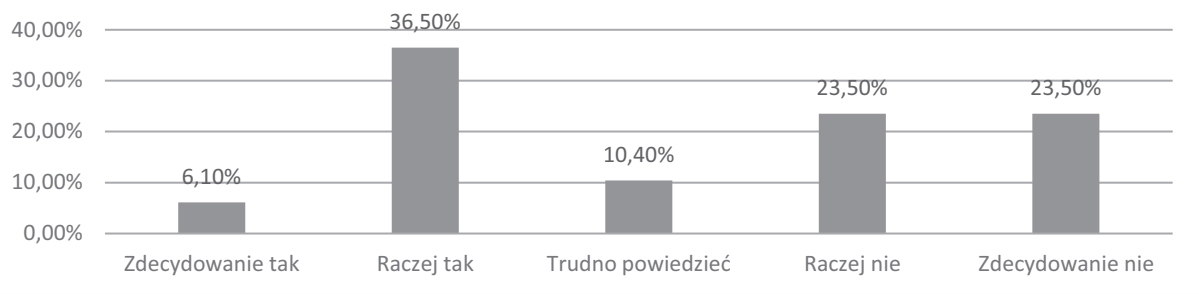

Ryc. 4. Procentowe odpowiedzi respondentów (nauczycieli akademickich) na pytanie o realizację celów edukacyjnych w trakcie nauczania zdalnego Źródło: opracowanie własne.

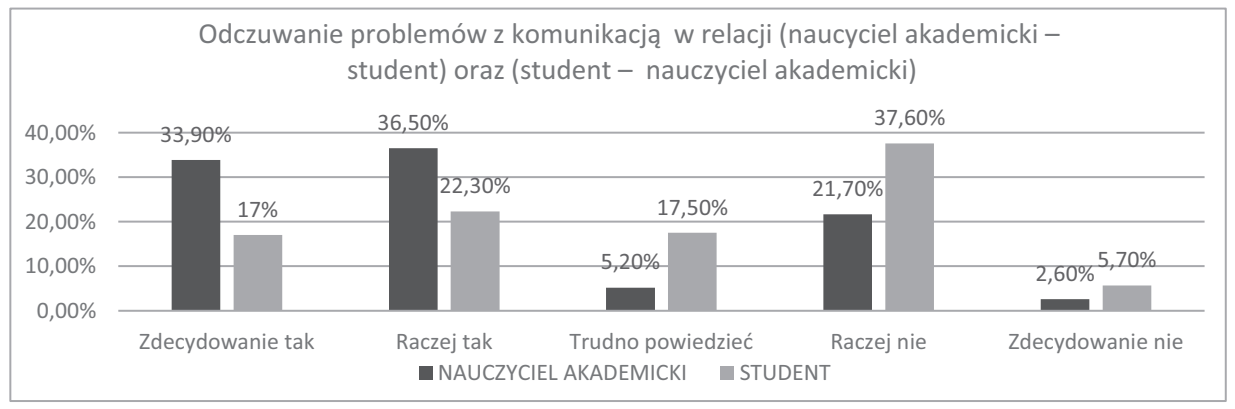

Ryc. 5. Problemy z komunikacją w trakcie nauczania zdalnego z perspektywy nauczyciela akademickiego oraz studenta

Źródło: opracowanie własne.

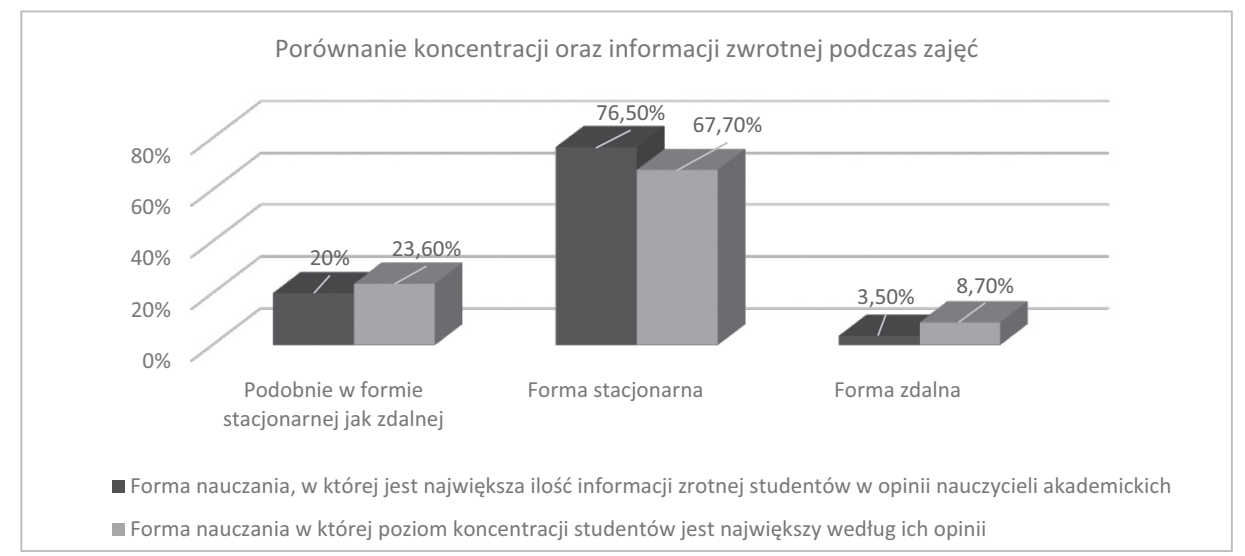

Ryc. 6. Zestawienie danych na temat trybu nauczania, w którym ilość informacji zwrotnej studentów jest największa w opinii nauczycieli akademickich, oraz trybu nauczania, w którym poziom koncentracji studentów jest największy.

Źródło: opracowanie własne. 
Poproszono również o wyrażenie opinii na temat efektywności nauczania zdalnego oraz zapytano respondentów, czy chcieliby korzystać z edukacji online. Wyniki podano na poniższych wykresach.
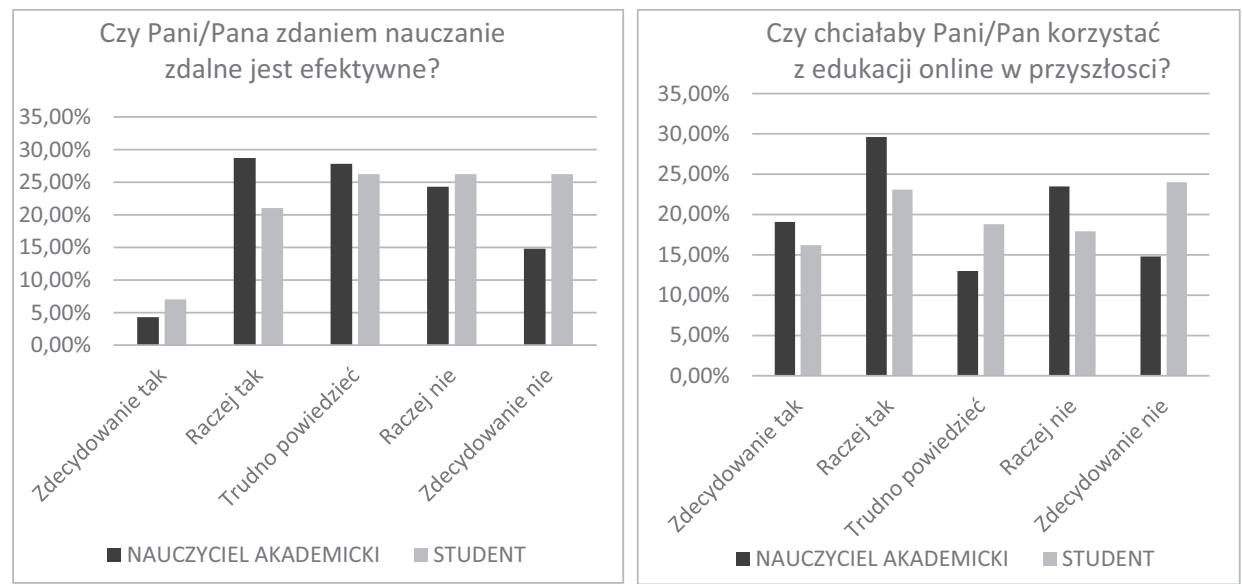

Ryc. 7. Chęć korzystania z edukacji online w przyszłości

Ryc. 8. Efektywność nauczania zdalnego według respondentów

Źródło: opracowanie własne.

Tabela 2. Zagrożenia i korzyści zdalnego nauczania z perspektywy nauczycieli akademickich oraz studentów

Zagrożenia zdalnego nauczania wskazywane przez nauczycieli akademickich

- konieczność dostosowania sposobu prowadzenia zajęć praktycznych, ćwiczeń, laboratoriów, tak aby były efektywne w postaci e-learningowej

- kosztowność przedsięwzięcia

- brak możliwości pełnej realizacji efektów uczenia się

- rezygnacja studentów ze studiów w formie zdalnej

- mniej informacji zwrotnej na temat zrozumienia przez studenta tematu

- pomijanie treści trudnych do przekazania w formie zdalnej / zaniżenie poziomu nauczania

- trudności w wyłapaniu osób, które nie radzą sobie z przyswajaniem przekazywanych treści

- trudność w rozwijaniu kompetencji społecznych

- konserwatyzm myślowy i konformizm części

kadry

- brak podstawowych umiejętności metodyczno-

-technicznych studentów

Zagrożenia zdalnego nauczania wskazywane przez studentów

- pogorszenie wzroku, wady postawy, zmniejszona aktywność fizyczna

- uzależnienie od komputera

- zależność od występowania problemów technicznych/sprzętowych oraz dostępu do Internetu, które mogą przekładać się na gorszą jakość kształcenia/pracy nad danym projektem (np. zakłócenia dźwięku lub niska jakość mikrofonu)

- trudności w przyswajaniu wiedzy

- wysyłanie materiałów zamiast przeprowadzenia wykładów wraz z objaśnieniem pewnych zagadnień

- brak wytycznych do realizacji projektu/ zadania 


\section{Zagrożenia zdalnego nauczania wskazywane przez obie grupy respondentów}

- brak kontaktu interpersonalnego z nauczycielami akademickimi oraz studentami (brak komunikacji poprzez gesty, mimikę)

- pogorszenie relacji, strach przed interakcją z drugą osobą, zanik umiejętności mówienia

- brak pracy zespołowej - zadania rozdzielane w taki sposób, aby każdy poradził sobie

z nimi indywidualnie (wynika z problemów w komunikacji między studentami)

- wycofywanie się z dyskusji (nieśmiałość studentów, brak warunków w miejscu pobytu - brak komfortu)

- ograniczona możliwość motywowania studentów do pracy na zajęciach, co wiąże się z brakiem odpowiedniego zaangażowania studentów (problem z automotywacją studentów)

- możliwość niesamodzielnej, nieuczciwej pracy studentów, utrudnienie rzetelnego nadzoru w czasie weryfikacji wiedzy i umiejętności, który wiąże się z niższym poziomem wiedzy przyszłych absolwentów

- brak możliwości przeprowadzania zajęć praktycznych (brak kontaktu ze sprzętem i technologiami), który powoduje ograniczenie możliwości nabycia odpowiednich kompetencji koniecznych w przyszłej karierze zawodowej, osiąganie słabszych efektów, brak właściwego opanowania umiejętności praktycznych

- ułatwiony dostęp do rozpraszaczy przy braku kontaktu wzrokowego prowadzącego

ze studentami

- wykluczenie osób nieposiadających dobrego dostępu do Internetu czy też odpowiedniego sprzętu elektronicznego

Korzyści zdalnego nauczania wskazywane przez nauczycieli akademickich

- wykorzystanie pewnych narzędzi (metod, form) dydaktycznych niedostępnych w przypadku zajęć realizowanych w formule tradycyjnej

- możliwości organizacji spotkań/webinariów

z gośćmi reprezentującymi otoczenie społeczno-biznesowe w sposób niegenerujący dla żadnej ze stron znaczących kosztów (finansowych, czasowych)

- przyspieszenie rozwoju narzędzi dydaktycznych

- dostęp do poprzednich etapów zadań domowych studentów

- możliwość wykorzystania zdecydowanie większej liczby narzędzi informatycznych w nauczaniu

- edukacja zdalna pozwala na mniejsze przerwy między zajęciami, co przekłada się na korzystniejszy harmonogram dla studentów oraz dla prowadzących
Korzyści zdalnego nauczania wskazywane przez studentów

- oszczędność pieniędzy (brak konieczności wynajmowania mieszkania, korzystania z transportu miejskiego)

- dostępność, praktycznie w każdym miejscu z dostępem do Internetu można uczestniczyć w zajęciach

- mniejszy stres

- ułatwiony dostęp do pomocy naukowych w trakcie zdawania egzaminów

- możliwość korzystania z edukacji zdalnej również przy złym samopoczuciu/chorobie

- możliwość łatwiejszego połączenia pracy zarobkowej z edukacją 


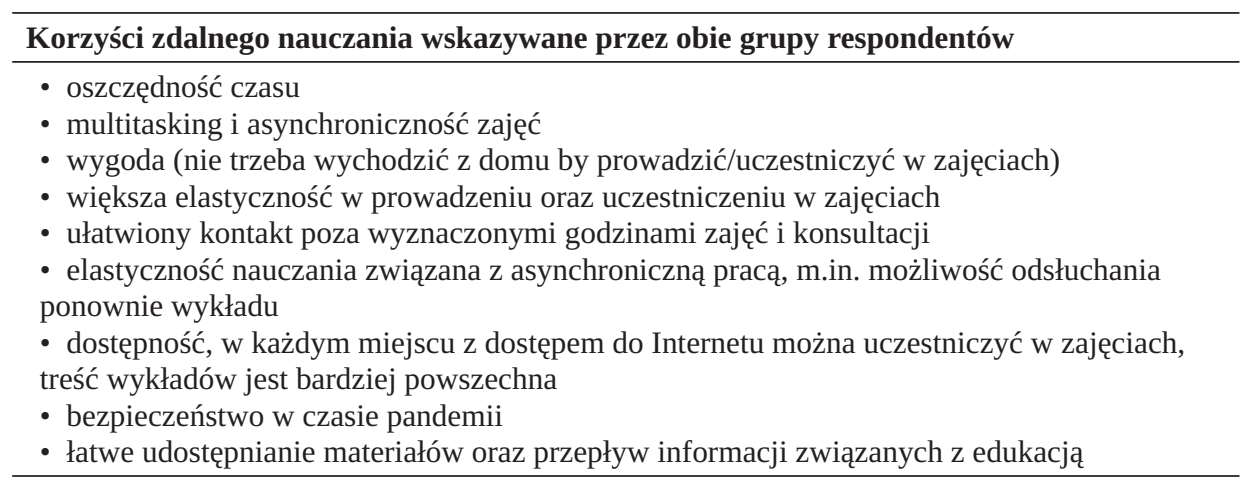

Źródło: opracowanie własne.

\section{PODSUMOWANIE, WNIOSKI KOŃCOWE ORAZ SUGESTIE}

Podsumowując, sytuacja epidemiczna na świecie spowodowała, że wykorzystywanie technologii komputerowej w edukacji stało się coraz bardziej powszechne, wręcz konieczne. Okoliczności te stworzyły idealny grunt do rozwoju nauczania oraz przełomowych odkryć. Studenci w dzisiejszych czasach oczekują łatwo dostępnych, aktualnych informacji, które zostaną przedstawione w sposób atrakcyjny, co w nauczaniu zdalnym ma miejsce. Warto jednak wziąć pod uwagę, iż powyższe badania wykazały, że duża część respondentów ma problemy w komunikacji w trakcie zajęć realizowanych zdalnie. Znacznie większe kłopoty z porozumiewaniem się w trakcie nauczania zdalnego odczuwają nauczyciele akademiccy w relacji (nauczyciel akademicki-student) niż studenci w relacji (student-nauczyciel akademicki). Okazuje się, że pomimo wielu korzyści e-learningu nic nie jest w stanie zastąpić fizycznej obecności drugiego człowieka, który zmotywuje do podjęcia działania, dostrzeże pewne braki, by odpowiednio szybko zareagować i wspomóc w zdobywaniu kolejnych umiejętności. Przedstawione wyniki wskazują, że największa ilość informacji zwrotnej studentów do nauczycieli akademickich podczas zajęć przejawiana jest w nauczaniu stacjonarnym, a co za tym idzie, ułatwiona jest komunikacja i możliwość dostosowania przedstawianego materiału. Ankietowani studenci wskazywali, że znacznie lepiej jest im się skoncentrować, będąc na uczelni; fakt ten podkreśla istotność fizycznego kontaktu z drugim człowiekiem, materiałem nauczanym oraz bodźcami, które są odbierane przez studentów w sali wykładowej, w trakcie ćwiczeń, laboratoriów, zajęć praktycznych. 
W związku z tym można stwierdzić, że najwięcej korzyści przynieść może edukacja w formie hybrydowej, która łączy podejście tradycyjne oraz zdalne. Nauczanie hybrydowe, w którym wykłady oraz seminaria prowadzone są online, a zajęcia praktyczne - takie jak ćwiczenia, laboratoria - w formie stacjonarnej, są uważane za najbardziej optymalne przez nauczycieli akademickich oraz studentów. Weryfikacja wiedzy (egzaminy, zaliczenia) według nich powinna odbywać się w formie stacjonarnej. Nowy model edukacji powinien opierać się na stwarzaniu warunków do samodzielnego uczenia się, odkrywania wiedzy, doświadczania i zdobywania informacji przy zachowaniu interakcji nauczyciel akademicki student.

\section{Bibliografia}

Barczak, A., Florek, J., Jakubowski, S., Sydoruk, T. (2006).Zd@lna edukacja - potrzeby, problemy, szanse i zagrożenia. Warszawa: Wydawnictwo Akademii Pedagogiki Specjalnej im. Marii Grzegorzewskiej, s. 32-47.

Bednarek, J., Lubina, E. (2008). Kształcenie na odległość. Podstawy dydaktyki. Warszawa: Wydawnictwo Naukowe PWN SA, s. 102.

Białobłocki, T., Moroz, J. (2006). Nowoczesne techniki informacji i komunikacji - ich rozwój i zastosowanie. W: M. Witkowska, K. Cholawo-Sosnowska (red.), Społeczeństwo inform@cyjne - istota, rozwój, wyzwania (s. 158). Warszawa: Wydawnictwa Akademickie i Profesjonalne.

Diarra, M., Kaczmarek, J. (2003). Nowoczesne technologie dla systemów zdalnej edukacji. Zeszyty Naukowe Wydziału Elektrotechniki i Automatyki Politechniki Gdańskiej, 19, XIII Seminarium Zastosowanie komputerów w nauce i technice. Oddział Gdański PTETiS.

Galwas, B. (2002) Internet jako wiodące narzędzie modelu studiów na odległość Politechniki Warszawskiej. W: S. Wrycza, J. Wojtkowiak (red.), Nauczanie na odległość. Wyzwania - tendencje - aplikacje (s. 170). Gdańsk: Wydawnictwo Uniwersytetu Gdańskiego.

Hojnacki, L. (2011). M-LEARNING, czyli (r)ewolucja w nauczaniu. Warszawa: Wydawnictwo Think Global sp. z o.o.

Kaplan, A. (2017). Academia Goes Social Media, MOOC, SPOC, SMOC, and SSOC: The digital transformation of Higher Education Institutions and Universities. In: B. Rishi, S. Bandyopadhyay (eds.), Contemporary Issues in Social Media Marketing. London: Routledge.

Mischke, J. (2004). Dylematy współczesnej edukacji; nauczanie tradycyjne czy zdalne? W: M. Tanaś (red.), Pedagogika @ środki informatyczne i media (s. 53). WarszawaKraków: Wydawnictwo IMPULS.

Rutkowska, L. (2002). Edukacja na odległość. Metodyka i oprogramowanie. W: S. Wrycza, J. Wojtkowiak (red.), Nauczanie na odległość. Wyzwania - tendencje - aplikacje (s. 61-62). Gdańsk: Wydawnictwo Uniwersytetu Gdańskiego. 
Stachowiak, B. (2012). Uwarunkowania efektów kształcenia Akademickiego. W: D. Ciechanowska (red.), Nauczyciele akademiccy a wykorzystywanie technologii informacyjno-komunikacyjnych w ocenie studentów (s. 233-241). Szczecin: Wydawnictwo OR TWP.

Syguła, A. (2013). Rola e-edukacji w rozwoju kształcenia akademickiego. W: M. Dąbrowski, M. Zając (red.), Smartfon jako narzędzie w procesie edukacji w szkole wyższej - możliwości i perspektywy zastosowania (s. 106-120). Warszawa: Fundacja Promocji i Akredytacji Kierunków Ekonomicznych.

Szkurłat, E. (2015). E-learning w geograficznym kształceniu akademickim - szanse, wyzwania, zagrożenia, Prace komisji edukacji geograficznej, Łódź, t. 5, s. 67-68.

Tanaś, M. (2004). Dydaktyczny kontekst kształcenia na odległość. W: M. Tanaś (red.), Pedagogika@ środki informatyczne i media (s. 36). Warszawa-Kraków: Wydawnictwo IMPULS. 